\title{
What is a preferred angiotensin II receptor blocker-based combination therapy for blood pressure control in hypertensive patients with diabetic and non-diabetic renal impairment?
}

\author{
Samir G Mallat
}

\begin{abstract}
Hypertension has a major associated risk for organ damage and mortality, which is further heightened in patients with prior cardiovascular (CV) events, comorbid diabetes mellitus, microalbuminuria and renal impairment. Given that most patients with hypertension require at least two antihypertensives to achieve blood pressure (BP) goals, identifying the most appropriate combination regimen based on individual risk factors and comorbidities is important for risk management. Single-pill combinations (SPCS) containing two or more antihypertensive agents with complementary mechanisms of action offer potential advantages over free-drug combinations, including simplification of treatment regimens, convenience and reduced costs. The improved adherence and convenience resulting from SPC use is recognised in updated hypertension guidelines. Despite a wide choice of SPCs for hypertension treatment, clinical evidence from direct head-to-head comparisons to guide selection for individual patients is lacking. However, in patients with evidence of renal disease or at greater risk of developing renal disease, such as those with diabetes mellitus, microalbuminura and high-normal BP or overt hypertension, guidelines recommend renin-angiotensin system (RAS) blocker-based combination therapy due to superior renoprotective effects compared with other antihypertensive classes. Furthermore, RAS inhibitors attenuate the oedema and renal hyperfiltration associated with calcium channel blocker (CCB) monotherapy, making them a good choice for combination therapy. The occurrence of angiotensin-converting enzyme (ACE) inhibitor-induced cough supports the use of angiotensin II receptor blockers (ARBs) for RAS blockade rather than ACE inhibitors. In this regard, ARB-based SPCS are available in combination with the diuretic, hydrochlorothiazide (HCTZ) or the calcium CCB, amlodipine. Telmisartan, a long-acting ARB with preferential pharmacodynamic profile compared with several other ARBs, and the only ARB with an indication for the prevention of CV disease progression, is available in two SPC formulations, telmisartan/HCTZ and telmisartan/amlodipine. Clinical studies suggest that in CV high-risk patients and those with evidence of renal disease, the use of an ARB/CCB combination may be preferred to ARB/ HCTZ combinations due to superior renoprotective and CV benefits and reduced metabolic side effects in patients with concomitant metabolic disorders. However, selection of the most appropriate antihypertensive combination should be dependent on careful review of the individual patient and appropriate consideration of drug pharmacology.
\end{abstract}

Keywords: Amlodipine, Angiotensin receptor II blocker, Diabetes mellitus, Hydrochlorothiazide, Hypertension, Renal impairment, Single-pill combination, Telmisartan

Correspondence: samir.mallat@aub.edu.lb

Division of Nephrology and Hypertension, Department of Internal Medicine,

Faculty of Medicine, American University of Beirut, Beirut, Lebanon 


\section{Introduction}

Hypertension is a highly prevalent disease with a major associated risk for cardiovascular (CV) morbidity and mortality [1-3]. The majority of patients with hypertension require more than one antihypertensive agent to achieve and maintain guideline-recommended blood pressure (BP) goals [4-8]. Identifying the most appropriate combination therapy for each patient based on individual risk factors and comorbidities is important for risk management. Increasingly, single-pill combinations (SPCs) containing two or more antihypertensive agents with complementary mechanisms of action are available. These offer potential advantages, including simplification of treatment regimens, more convenient drug administration and reduced healthcare costs $[5,9,10]$. Evidence from meta-analyses has shown that the use of antihypertensive SPCs compared with corresponding free-drug combinations is associated with significantly greater rates of treatment adherence to medication and potential advantages in terms of BP improvements and adverse effects [11,12]. A large retrospective database study of an angiotensin II receptor blocker (ARB) plus a calcium channel blocker (CCB) in two-drug SPCs has also shown greater levels of adherence compared with the corresponding free-pill ARB/ CCB regimens [13]. Treatment adherence is an important issue for a chronic disease such as hypertension, with improvements in adherence expected to result in better long-term clinical outcomes, including reduced $\mathrm{CV}$ and renal morbidity/mortality. This review will consider the choice of agents for combination therapy using two-drug SPCs and the rationale for using particular combinations in patients with hypertension and renal impairment.

\section{Why should early combination therapy be considered?}

Worldwide guidelines recommend combination therapy as a first-line treatment option for hypertension likely not to be controlled on monotherapy (e.g. 20/10 mmHg above target BP) because of evidence showing that only a minority of patients will achieve and maintain BP goals on monotherapy [5-8,14]. The recent re-appraisal of the European guidelines also recommended the preferential use of SPCs to improve adherence [7].

There are a number of compelling reasons why early combination therapy should be used in patients with hypertension (Table 1), including lack of efficacy with monotherapy, greater BP control and attenuation of side effects associated with monotherapeutic treatment [15-20]. In addition, hypertensive patients with comorbidities, such as renal disease, might benefit from additional effects of multiple antihypertensive agents, beyond those related to BP lowering [10].

\section{What are the preferred drug classes for combination regimens?}

A range of mostly two-drug antihypertensive SPCs is available [10]. Preferred drug classes for combination regimens target the renin-angiotensin system (RAS), such as ARBs and angiotensin-converting enzyme (ACE) inhibitors, CCBs and diuretics, with selection dependent on individual patient factors, including additional CV risk factors and comorbidities $[4,7]$. For example, in patients with diabetes and high-normal BP or overt hypertension, which together confer a greater risk of renal damage, combination therapy with a RAS blocker is preferred because these agents offer a superior protective effect against initiation and progression of nephropathy [6]. In patients with renal disease, antihypertensive therapy should aim to target a range of markers of renal (and CV) risk, such as serum creatinine, urine albumin:creatinine ratio, microalbuminuria and proteinuria, usually by RAS blockade, with a view to reducing and slowing progression to end-stage renal disease (ESRD) and CV events [6,20]. Microalbuminuria in particular is a marker of global CV risk and is very common in patients with hypertension [22]. Several position statements also recommend combined therapy that includes RAS blockers. The American Society of Hypertension indicated a preference for RAS blockers in combination with either a diuretic or CCB, with SPCs rather than separate agents preferred when convenience outweighs all other considerations [23]. In addition, the International Society on Hypertension in Blacks (IHSB) recommend a RAS blocker-diuretic or CCB combination in patients with $\mathrm{BP}>15 / 10 \mathrm{mmHg}$ above the target goal [24]. IHSB guidance extends to recommending combination with $\mathrm{CCB}$ over diuretics where appropriate (in absence of oedema and/or volume-overload states) due to superiority for hard clinical outcomes.

Owing to the CV and renal protective effects of RAS inhibitors, dual RAS blockade is currently under investigation, i.e. ACE inhibitors, ARB combinations and direct renin inhibitor (DRI) combinations. However studies of double RAS blockade in high-risk patients have provided mixed results [25-28] and current evidence therefore, does not support this therapeutic approach [29].

SPCs containing an ARB may be preferred over those containing ACE inhibitors. ARBs have superior tolerability over ACE inhibitors, which inhibit the degradation of bradykinin, leading to adverse effects, such as dry cough and angioedema [30,31]. Several studies have shown that treatment with ARBs is associated with significantly lower rates of cough and angioedema versus ACE inhibitors [32,33]. Furthermore, ARBs (in particular telmisartan) are well tolerated in patients who are intolerant of ACE inhibitors [34]. Due to their superior tolerability, ARBs may be associated with a higher rate of adherence 
Table 1 Rationale for and potential advantages of early SPC antihypertensive therapy $[10,15,16,21]$

\begin{tabular}{|c|c|}
\hline \multicolumn{2}{|c|}{ Rationale: } \\
\hline & Monotherapy is not effective at reaching and maintaining BP goal in most patients \\
\hline & Each difference of $20 \mathrm{mmHg}$ usual SBP or $10 \mathrm{mmHg}$ usual DBP is associated with a two-fold increase in vascular death \\
\hline 3. & Using lower doses of each agent reduces the likelihood of adverse events experienced with a single agent used at a higher dose \\
\hline 4. & $\begin{array}{l}\text { Patients with comorbidities, such as renal disease, might benefit from the non-BP-lowering benefits of antihypertensive agents with } \\
\text { complementary mechanisms of action }\end{array}$ \\
\hline \multicolumn{2}{|c|}{ Potential advantages: } \\
\hline & Simplified treatment regimen, which is particularly relevant in older patients with comorbid diseases requiring complicated polytherapy \\
\hline & Increased adherence and persistence compared with equivalent free-drug combinations \\
\hline & Additive effects on BP control of individual components with different, complementary mechanisms of action \\
\hline & $\begin{array}{l}\text { Attenuation of recognised adverse events, such as reduced CCB-induced peripheral oedema and diuretic-induced metabolic changes with RAS } \\
\text { blockers }\end{array}$ \\
\hline & Lower costs through increased BP reductions \\
\hline
\end{tabular}

Abbreviations: $\mathrm{BP}=$ blood pressure; $\mathrm{CCB}=$ calcium channel blocker; $\mathrm{DBP}=$ diastolic blood pressure; $\mathrm{RAS}=$ renin-angiotensin system; SBP = systolic blood pressure; SPC = single-pill combination

than ACE inhibitors. In a large cohort of patients in Italy, the rate of discontinuation of the initial single antihypertensive drug treatment was lower for ARBs compared with ACE inhibitors (hazard ratio [HR], 0.92; 95\% confidence interval [CI], 0.90-0.94) [35].

In addition to increasing the BP-lowering effects of thiazides and CCBs, adding a RAS inhibitor may help to attenuate the unfavourable metabolic side effects of thiazide monotherapy [36] and CCB-induced peripheral oedema [37-40]. CCB-induced peripheral oedema, which is most likely to occur with dihydropyridine calcium antagonists[41], is caused by increased capillary pressure and flow leading to increased permeability and fluid hyperfiltration [42], appears to be abrogated by post-capillary dilation and normalisation of hydrostatic pressure induced by RAS blockers [43]. Although attenuation of CCBinduced oedema may not as great as that seen with $\mathrm{ACE}$ inhibitors [44], ARBs may still be the preferred choice of RAS inhibitor due to their superior tolerability.

In addition to providing superior tolerability over ACE inhibitors, clinical trials have also demonstrated that the ARBs, in particular telmisartan, provide superior BP lowering to ACE inhibitors in the early morning as well as in the 24-hour, morning, daytime and night-time periods [45-50].

Hyperlipidaemia is another prevalent condition in hypertensive patients. Clinical data indicate that ARBs have no effect on lipid metabolism and are therefore safe to use in patients with hyperlipidaemia [51,52], supporting their selection in combined therapy for a broad patient population. In relation to safety, one analysis suggested that ARBs may be associated with a modest risk of lung cancer [53]; however, more complete analyses of current data have refuted this statement $[54,55]$.

Finally, there is a wealth of data supporting the use of ARBs in diabetic patients [56], adding to the rationale for selecting this drug class for combined treatment in diabetic patients with renal impairment. ARBs and ACE inhibitors are considered equivalent in patients with type II diabetes mellitus (T2DM) with microalbuminuria. However, in patients with T2DM with proteinuria and/or renal insufficiency, ARBs are recommended because randomised controlled trials have shown that ARBs delay the progression of nephropathy in these patients [57]. Furthermore, clinical data suggest that ARBs may delay development of diabetes in at-risk patients and therefore prevent $\mathrm{CV}$ events in high-risk patients [56,57].

The other RAS blocker for consideration is aliskiren, a direct renin inhibitor. SPCs comprising aliskiren with a CCB or diuretic are also available. Data suggest DRIs and conventional RAS inhibitors exert similar levels of BP control [58]. However, unlike ACE inhibitors and ARBs, there is currently very limited data on the effect of aliskiren on CV and renal outcomes. The ALiskiren Trial in Type 2 diabetes Using carDio-renal Endpoints (ALTITUDE) study aimed to assess the effectiveness of alikiren in reducing $\mathrm{CVr}$ and renal events in patients with $\mathrm{T} 2 \mathrm{DM}$ [59], but it was stopped early due to lack of efficacy and increased side effects, such as non-fatal stroke, renal complications, hyperkalemia and hypotension. Ongoing studies will hopefully provide these much-needed data. As there is currently little evidence to support DRI use in this patient population, we will not consider it further in this review.

\section{What are the preferred partners for ARB-based combinations, and why might telmisartan be a preferred ARB choice?}

Most currently available ARB-based SPCs in Europe combine an ARB with either the thiazide diuretic, hydrochlorothiazide (HCTZ), or the CCB, amlodipine (Table 2) [23]. 
Table 2 Currently authorised ARB-based two-drug SPC antihypertensive therapy in Europe in 2011 [69]

\begin{tabular}{lcc}
\hline ARB & HCTZ combination & CCB combination \\
\hline Telmisartan & $\checkmark$ & $\checkmark$ \\
\hline Valsartan & $\checkmark$ & $\checkmark$ \\
\hline Olmesartan & $\checkmark$ & $\checkmark$ \\
\hline Losartan & $\checkmark$ & \\
\hline Irbesartan & $\checkmark$ & \\
\hline Candesartan & & \\
\hline Eprosartan & & \\
\hline Azilsartan & & \\
\hline
\end{tabular}

Abbreviations: $\mathrm{ARB}=$ angiotensin II receptor blocker; $\mathrm{CCB}=$ calcium channel blocker; $\mathrm{HCTZ}$ = hydrochlorothiazide; SPC = single-pill combination

A number of clinical trials have demonstrated the superior antihypertensive efficacy of ARB/HCTZ combinations [60-63] and ARB/CCB combinations [40,64-68] compared with monotherapy.

Currently, there are eight ARBs marketed for hypertension: azilsartan, candesartan, eprosartan, irbesartan, losartan, olmesartan, telmisartan and valsartan. Owing to their molecular differences, these agents demonstrate considerable variation in their pharmacokinetic and pharmacodynamic properties, which are likely to affect clinical efficacy [70]. These differences relate to lipophilicity, volume of distribution, bioavailability, biotransformation, plasma half-life, receptor affinity and residence time, as well as elimination [70,71]. The long-lasting antihypertensive effects of telmisartan compared with other ARBs are likely due to this agent having the longest plasma elimination half-life of approximately 24 hours (Table 3), as well as the highest affinity for the $\mathrm{AT}_{1}$ receptor [70-72]. As the most lipophilic of the ARBs, telmisartan also has the highest volume of distribution, which facilitates tissue/organ penetration (Table 3) [70-73]. Moreover, as a partial agonist of peroxisome proliferator-activated receptor-gamma, telmisartan may offer advantages in patients with insulin resistance and glucose intolerance, as well as hypertension $[74,75]$. These unique characteristics of telmisartan manifest in a number of clinical advantages, such as long-lasting $\mathrm{BP}$ control and $\mathrm{CV}$ protection - consequently telmisartan has been identified as a gold-standard treatment and has been recommended as a preferred ARB treatment option [76,77]. Furthermore, telmisartan has been recognised as an important therapeutic option for type 2 diabetes patients in the optimisation of $\mathrm{CV}$ and renal prevention [78]. These endorsements nominate telmisartan as the preferred ARB choice in combination therapy.

Several studies have demonstrated the superiority of telmisartan compared with other ARBs regarding 24hour BP-lowering efficacy, particularly in the early morning period [80-86]. When a smoothness index was used to evaluate the 24-hour antihypertensive efficacy of several agents, telmisartan $80 \mathrm{mg}$ had a significantly higher smoothness index than the ARBs losartan and valsartan and the ACE inhibitor, ramipril, and was comparable with amlodipine [87]. Telmisartan effectively reduces $\mathrm{BP}$ when used alone $[32,34,88,89]$ or in combination with HCTZ $[86,90-94]$ or amlodipine $[37,95,96]$. Telmisartan/HCTZ has demonstrated superiority over losartan/HCTZ in patients with essential hypertension in terms of 24-hour ambulatory BP, including a BP-lowering effect during the last 6 hours of the dosing interval $[92,97,98]$. In the Study of Micardis ${ }^{\circledR}$ on Obese/Overweight Type-II diabetics with Hypertension $\left(\mathrm{SMOOTH}^{\circledR}\right)$, telmisartan/HCTZ demonstrated significantly greater reductions in mean ambulatory $\mathrm{BP}$ over the entire 24-hour dosing interval and during the last 6 hours compared with valsartan/HCTZ [93]. In two large, placebocontrolled trials, telmisartan/HCTZ also demonstrated antihypertensive superiority over valsartan/HCTZ in patients with stages 1 and 2 hypertension [86,94].

In patients with renal impairment, there are limited data on the efficacy of telmisartan/HCTZ compared with placebo, telmisartan monotherapy or other ARB-based combinations. The Diabetics Exposed to Telmisartan And enalaprIL (DETAIL ${ }^{\circledR}$ ) study, in which more than $80 \%$ of enrolled patients had microalbuminuria, confirmed the efficacy of telmisartan in combination with a diuretic [99]. Switching patients with poorly controlled hypertension and mild-to-moderate chronic kidney disease from high-dose ARBs to telmisartan $40 \mathrm{mg} / \mathrm{HCTZ}$ $12.5 \mathrm{mg}$ provided additional BP reductions and reduced urinary protein excretion, suggesting the combination is effective in this patient population [100]. Telmisartan/ HCTZ has also demonstrated excellent tolerability. A retrospective safety analysis of 50 studies that evaluated telmisartan either as monotherapy or combined with HCTZ confirmed that the addition of HCTZ did not have a negative impact on the excellent tolerability profile of telmisartan, which is comparable with placebo [101]. Similar tolerability profiles have been reported for other ARB/ HCTZ combinations [102-104].

Studies have also confirmed the therapeutic advantages of telmisartan and amlodipine combined therapy versus the monotherapies on reaching and maintaining BP goals in hypertensive patients $[37,95,96,105]$. Subgroup analysis of a trial conducted in patients with moderate-to-severe hypertension demonstrated that the telmisartan/amlodipine combination yielded reductions in mean seated trough systolic BP (SBP)/diastolic BP of up to -25.7/-19.5 $\mathrm{mmHg}$ in patients with mild renal impairment (estimated glomerular filtration rate $[G F R] \geq 60 \mathrm{ml} / \mathrm{min} / 1.73 \mathrm{~m}^{2}$ ) and $-26.5 /-20.8 \mathrm{mmHg}$ in patients with moderate-to-severe renal impairment (estimated GFR $<60 \mathrm{ml} / \mathrm{min} / 1.73 \mathrm{~m}^{2}$ ) [106]. The BP goal of $<140 / 90 \mathrm{mmHg}$ was achieved in up 
Table 3 Pharmacokinetic properties of ARBs [49,50,79]

\begin{tabular}{|c|c|c|c|c|c|c|}
\hline & $t_{\max }(h)$ & Bioavailability (\%) & $\begin{array}{c}T_{1 / 2} \\
(h)\end{array}$ & $\begin{array}{l}\text { Vd } \\
(L)\end{array}$ & Interaction with food & Hepatic elimination (\%) \\
\hline Candesartan & $3.0-5.0$ & 42 & $9-13$ & $0.13(\mathrm{~L} / \mathrm{kg})$ & No & 67 \\
\hline Eprosartan & $2.0-6.0$ & 13 & $5-7$ & 308 & No & 90 \\
\hline Irbesartan & $1.0-2.0$ & $60-80$ & $12-20$ & $53-93$ & No & 80 \\
\hline Losartan & $1.0(3.0-4.0)^{1}$ & 33 & $2(4-6)^{1}$ & $34(12)^{1}$ & No & 60 \\
\hline Olmesartan & $1.4-2.8$ & $26^{2}$ & $11.8-14.7$ & $15-20$ & No & $51-66^{3}$ \\
\hline Telmisartan & 1 & 43 & 24 & 500 & No & $>98^{4}$ \\
\hline Valsartan & 2 & 23 & 7 & 17 & No & 83 \\
\hline Azilsartan & $1.5-3.0$ & 60 & 11 & 16 & No & 55 \\
\hline \multicolumn{7}{|c|}{$\begin{array}{l}\text { Abbreviations: } A R B=\text { angiotensin II receptor blocker; } t_{1 / 2}=\text { terminal elimination half-life; } t_{\max }=\text { time to maximum plasma concentration; } V d=\text { volume of } \\
\text { distribution }\end{array}$} \\
\hline \multicolumn{7}{|c|}{${ }^{1}$ Values in parentheses are for the active metabolite of losartan } \\
\hline \multirow{2}{*}{\multicolumn{7}{|c|}{${ }^{3}$ Based on urinary recovery rate for intravenous olmesartan }} \\
\hline ecove & r telmisartan & & & & & \\
\hline
\end{tabular}

to $76.6 \%$ of patients with mild renal impairment and in up to $75.0 \%$ of those with moderate-to-severe renal impairment [106]. In a separate 8-week, randomised, doubleblind trial in patients with T2DM and stages 1 or 2 hypertension ( $\mathrm{SBP}>150 \mathrm{mmHg}$ ), the telmisartan/amlodipine combination was superior as initial therapy compared with amlodipine $10 \mathrm{mg}$ [107]. The BP goal of 140/90 $\mathrm{mmHg}$ was reached by $71.4 \%$ of patients treated with the telmisartan/amlodipine SPC compared with $53.8 \%$ of those treated with amlodipine $10 \mathrm{mg}$ alone. For the more stringent BP goal of $\leq 130 / 80 \mathrm{mmHg}$, these rates were $36.4 \%$ and $17.9 \%$ for the telmisartan/amlodipine and amlodipine $10 \mathrm{mg}$ groups, respectively.

Further to the beneficial outcomes on BP, the addition of telmisartan has been shown to reduce the incidence of peripheral oedema induced by amlodipine [37]. This effect is thought to be mediated by the reduction of CCBinduced renal hyperfiltration and proteinuria - in a recent clinical study, where a 70\% decrease in the urine albuminto-creatinine ratio (UACR) was seen in those patients treated with a telmisartan and amlodipine combination compared with amlodipine monotherapy (Figure 1) [107].

What is the preferred combination therapy for patients with renal impairment?

RAS blockers are the recommended choice of treatment for patients with renal impairment [108]. When faced with hypertensive patients with evidence of renal damage, the physician should consider the use of an ARB-based SPC, for tolerability reasons. Choices are numerous but often result in a choice between $\mathrm{ARB} / \mathrm{CCB}$ and $\mathrm{ARB} / \mathrm{HCTZ}$, and it is therefore prudent to consider the evidence for these two combination types in patients with renal impairment.

In a randomised, open-label study that compared urinary albumin excretion in 207 hypertensive patients during treatment with the $\mathrm{ARB}$, olmesartan, in combination with either HCTZ or the CCB, azelnidipine, ARB/ HCTZ decreased UACR significantly more. This was clearly associated with greater reductions in night-time SBP, suggesting that the differential renal effects were due to differences in BP lowering [109]. In the Avoiding Cardiovascular events through COMbination therapy in Patients LIving with Systolic Hypertension (ACCOMPLISH) trial involving 11,506 patients, treatment with the ACE inhibitor, benazepril, combined with amlodipine was associated with a significant risk reduction for renal disease progression, as well as $\mathrm{CV}$ disease events, compared with benazepril/HCTZ in hypertensive

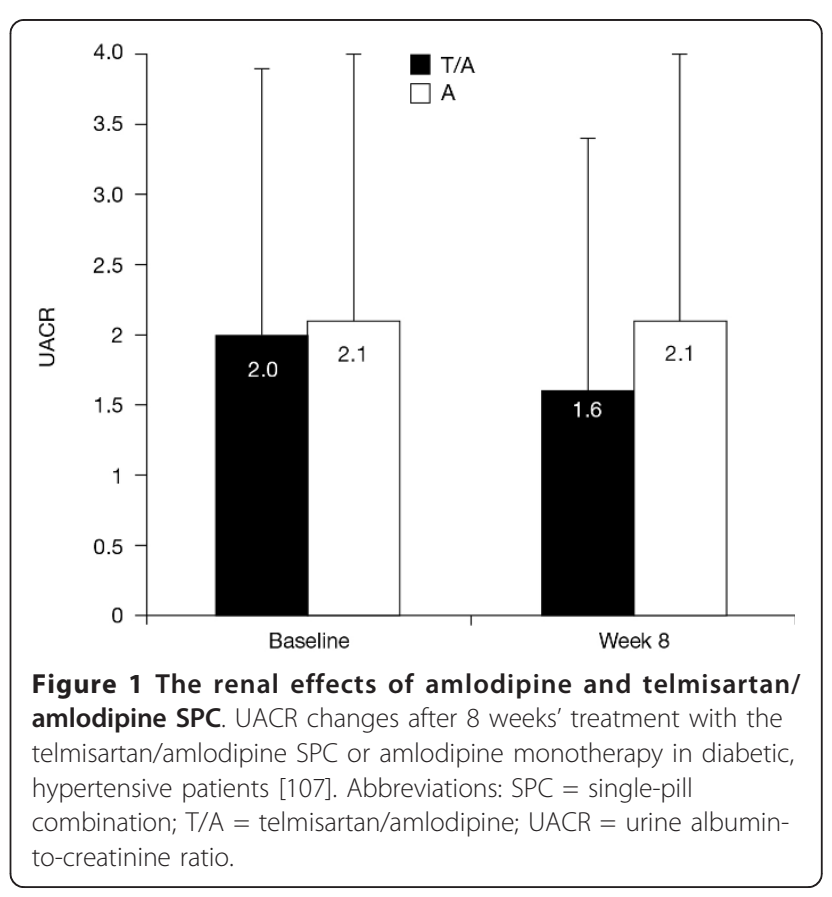


patients at high risk for CV events. Indeed, $2.0 \%$ of patients experienced chronic kidney disease progression in the benazepril/amlodipine group compared with 3.7\% in the benazepril/HCTZ group (HR, 0.52; 95\% CI, 0.41$0.65 ; \mathrm{p}<0.0001$ ) [110]. Around 18\% of patients enrolled in the ACCOMPLISH trial had an estimated GFR of $<$ $60 \mathrm{ml} / \mathrm{min} / 1.73 \mathrm{~m}^{2}$, suggestive of renal disease and $6.1 \%$ were defined as having renal disease based on serum creatinine levels or the presence of macroalbuminuria [111]. The differences in the renoprotective effects of the two combinations are unlikely to be due to differences in the level of BP control because 24-hour ambulatory $\mathrm{BP}$ control was comparable in the two treatment arms $[112,113]$. The significantly greater renoprotective effects provided by the RAS blocker combined with amlodipine rather than HCTZ are more likely due to metabolic or haemodynamic properties of the specific combination [112,113].

The view that thiazide diuretics reduce GFR and have lower efficacy in the renally impaired may also impact the efficacy and renoprotective outcome of combined therapy. Consequently, loop diuretics rather than thiazide diuretics are specifically recommended in patients with ESRD/proteinuria because they more readily increase diuresis at lower GFRs [6,7].

These findings suggest that a RAS blocker, combined with a CCB rather than HCTZ, may be the combination of choice for high $\mathrm{CV}$ risk hypertensive patients, such as those with coronary artery disease with or without stable angina, patients with a metabolic risk profile (e.g. diabetes, obesity or metabolic syndrome) and, in particular, those with renal disease. In addition, it should be noted that some data suggests thiazide diuretics may impair glucose homeostasis and that treatment is associated with a greater incidence of diabetes compared with other antihypertensives $[114,115]$. Furthermore, compared with olmesartan/HCTZ, olmesartan/amlodipine treatment was associated beneficial metabolic and inflammatory effects and a lower-risk of new onset diabetes in non-diabetic patients with metabolic syndrome [116]. These data reinforce the suggestion that ARB/ $\mathrm{CCB}$ combinations may be a preferred treatment combination, especially in patients with concomitant metabolic disorders, such as diabetes.

The renoprotective effects of ARBs and ACE inhibitors are mediated via their ability to block RAS activity [117]. This makes RAS blockers the treatment of choice in patients with diabetic kidney disease and non-diabetic kidney disease with proteinuria [108]. For the ARBs, evidence for guideline recommendations came from a number of clinical trials (predominantly in patients with chronic kidney disease) that showed ARBs to be renoprotective, independent of their BP-lowering effects (Table 4). For example, the IRbesartan in patients with type II diabetes and MicroAlbuminuria (IRMA2) study demonstrated that irbesartan, added to other antihypertensive agents, could prevent the development of diabetic nephropathy in hypertensive patients with T2DM and persistent microalbuminuria [118]. Also in patients with T2DM, the Irbesartan in Diabetic Nephropathy Trial (IDNT) demonstrated that irbesartan significantly reduced the risk of the composite primary endpoint of a doubling of serum creatinine, ESRD or death compared with placebo and amlodipine [119]. Losartan also demonstrated renoprotective effects in the Angiotensin II Antagonist Losartan (RENAAL) study [120]. In addition, the MicroAlbunuria Reduction with VALsartan (MARVAL) study showed greater reduction in urinary albumin excretion rate with valsartan than amlodipine for the same BP reduction [106,121].

In hypertensive patients, telmisartan has demonstrated renoprotective effects. In the DETAIL ${ }^{\circledR}$ study, telmisartan was not inferior to the ACE inhibitor, enalapril, in providing long-term renoprotection as measured by change in GFR in patients with T2DM [99]. The inVestigate the efficacy of telmIsartan versus VALsartan in hypertensive type II DIabetic patients with overt nephropathy $\left(\right.$ VIVALDI $^{\circledR}$ ) study demonstrated that telmisartan and valsartan provided similar levels of renoprotection in T2DM patients with overt nephropathy, as measured by changes in 24-hour urinary protein excretion rate, 24hour urinary albumin excretion rate and estimated GFR [124]. In contrast, telmisartan demonstrated superior efficacy in reducing proteinuria compared with losartan, despite similar BP reductions in hypertensive T2DM patients with overt nephropathy [122].

Telmisartan has also shown efficacy in non-hypertensive patients. Based on the findings of the ONgoing Telmisartan Alone and in combination with Ramipril Global Endpoint Trial (ONTARGET ${ }^{\circledR}$ ), which randomised 25,620 patients with vascular disease or diabetes with end-organ damage, to receive either telmisartan or the reference standard ACE inhibitor, ramipril, or a combination of the two agents [32], telmisartan is the only $\mathrm{ARB}$ with an indication for $\mathrm{CV}$ prevention independent of BP, including diabetes patients with established end organ damage such as renal disease. ONTARGET ${ }^{\circledR}$ demonstrated that the two agents were equally effective in reducing the primary composite outcome of CV death, myocardial infarction, stroke or hospitalisation due to heart failure (relative risk, 1.01; 95\% CI, 0.94-1.09), but that telmisartan was better tolerated than ramipril [32]. Previously, ramipril had demonstrated CV prevention properties in the Heart Outcomes Prevention Evaluation (HOPE) study [125]. Evidence from the ONTARGET ${ }^{\circledR}$ and the Telmisartan Randomized AssessmeNt Study in ACE-I iNtolerant subjects with cardiovascular Disease (TRANSCEND ${ }^{\circledR}$ ) trials also 
Table 4 Results of clinical trials indicating the renoprotective nature of ARBs

\begin{tabular}{|c|c|c|c|c|c|}
\hline Study & Patients & $\mathrm{n}$ & Treatment & Duration & Principle findings \\
\hline $\begin{array}{l}\mathrm{AMADEO}^{\circledR} \\
{[122]}\end{array}$ & $\begin{array}{l}\text { Hypertension and diabetic } \\
\text { nephropathy }\end{array}$ & 860 & $\begin{array}{l}\text { Telmisartan or } \\
\text { losartan }\end{array}$ & 52 weeks & Telmisartan was superior to losartan in reducing proteinuria \\
\hline CALM [25] & $\begin{array}{l}\text { Type } 2 \text { diabetes with } \\
\text { hypertension and } \\
\text { microalbuminuria }\end{array}$ & 199 & $\begin{array}{l}\text { Candesartan, } \\
\text { lisinopril or } \\
\text { both }\end{array}$ & 24 weeks & $\begin{array}{l}\text { Candesartan was as effective as lisinopril in reducing UACR. Combined } \\
\text { treatment was associated with a greater reduction in UACR than } \\
\text { monotherapeutic treatment (statistically significant versus candesartan } \\
\text { monotherapy) }\end{array}$ \\
\hline $\begin{array}{l}\text { DETAIL }^{\circledR} \\
{[99]}\end{array}$ & $\begin{array}{l}\text { Hypertension, Type } 2 \\
\text { diabetes and early } \\
\text { nephropathy }\end{array}$ & 250 & $\begin{array}{l}\text { Telmisartan or } \\
\text { enalapril }\end{array}$ & 5 years & $\begin{array}{l}\text { Telmisartan was not inferior to enalapril in providing long-term } \\
\text { renoprotection }\end{array}$ \\
\hline IDNT [119] & $\begin{array}{l}\text { Hypertension and diabetic } \\
\text { nephropathy }\end{array}$ & 1715 & $\begin{array}{l}\text { Irbesartan, } \\
\text { amlodipine or } \\
\text { placebo }\end{array}$ & $\begin{array}{l}\text { Mean } 2.6 \\
\text { years }\end{array}$ & $\begin{array}{l}\text { Irbesartan was superior to amlodipine and placebo in preventing the } \\
\text { primary composite end point of: a doubling of the base-line serum } \\
\text { creatinine concentration, the development of ESRD, or death from any } \\
\text { cause. This was independent of BP }\end{array}$ \\
\hline $\begin{array}{l}\text { IRMA } 2 \\
{[118]}\end{array}$ & $\begin{array}{l}\text { Hypertension, type } 2 \\
\text { diabetes and } \\
\text { microalbuminuria }\end{array}$ & 590 & $\begin{array}{l}\text { Irbesartan or } \\
\text { Placebo }\end{array}$ & 2 years & Irbesartan was superior to placebo in preventing diabetic nephropathy \\
\hline $\begin{array}{l}\text { MARVAL } \\
\text { [121] }\end{array}$ & $\begin{array}{l}\text { Diabetic nephropathy with } \\
\text { and without hypertension }\end{array}$ & 332 & $\begin{array}{l}\text { Valsartan or } \\
\text { amlodipine }\end{array}$ & 24 weeks & Valsartan was superior to amlodipine in reducing microalbuminuria \\
\hline $\begin{array}{l}\text { RENAAL } \\
{[120]}\end{array}$ & Diabetic nephropathy & 1513 & $\begin{array}{l}\text { Losartan or } \\
\text { placebo }\end{array}$ & $\begin{array}{l}\text { Mean } 3.4 \\
\text { years }\end{array}$ & $\begin{array}{l}\text { Losartan was superior to placebo in preventing increases in UACR and } \\
\text { progression to ESRD. There was no difference in mortality }\end{array}$ \\
\hline $\begin{array}{l}\text { ROADMAP } \\
{[123]}\end{array}$ & $\begin{array}{l}\text { Type } 2 \text { diabetes with } \\
\text { normoalbuminuria }\end{array}$ & 4449 & $\begin{array}{l}\text { Olmesartan or } \\
\text { placebo }\end{array}$ & $\begin{array}{l}\text { Median } \\
3.2 \text { years }\end{array}$ & $\begin{array}{l}\text { Olmesartan delayed the time to onset of microalbuminuria (statistical } \\
\text { significance lost on adjustment for blood pressure difference) }\end{array}$ \\
\hline $\begin{array}{l}\text { VIVALDI }^{\circledR} \\
{[124]}\end{array}$ & $\begin{array}{l}\text { Hypertension and diabetic } \\
\text { nephropathy }\end{array}$ & 885 & $\begin{array}{l}\text { Telmisartan or } \\
\text { valsartan* }\end{array}$ & 52 weeks & Telmisartan and valsartan provided similar renoprotection \\
\hline
\end{tabular}

Abbreviations: $\mathrm{AMADEO}^{\circledR}=\mathrm{A}$ trial to compare telMisartan $40 \mathrm{mg}$ titrated to $80 \mathrm{mg}$ versus losArtan 50 mg titrated to 100 mg in hypertensive type 2 DiabEtic patients with Overt nephropathy; $\mathrm{ARB}=$ angiotensin II receptor blocker; $\mathrm{BP}=$ blood pressure; $\mathrm{CALM}=\mathrm{CAndesartan}$ and Lisinopril Microalbuminuria; $\mathrm{DETAIL}^{\circledR}=$ Diabetics Exposed to Telmisartan And enalaprlL study; ESRD, end-stage renal disease; IDNT = Irbesartan type II Diabetic Nephropathy Trial; IRMA2 = IRbesartan in patients with type 2 diabetes and MicroAlbuminuria; MARVAL = MicroAlbuminuria Reduction with VALsartan trial; RENAAL = Reduction of Endpoints in NIDDM with the Angiotensin II Antagonist Losartan; ROADMAP = Randomized Olmesartan And Diabetes Microalbuminuria Prevention; UACR = urine albumin:Creatinine ratio; VIVALDI $^{\circledR}=\mathrm{A}$ trial to inVestigate the efficacy of telmlsartan versus VALsartan in hypertensive type 2 Dlabetic patients with overt nephropathy.

*Additional hypertensive treatment was allowed in VIVALDI ${ }^{\circledR}$.

provides support for the renoprotective effects of telmisartan [126-128].

Guidelines recommend RAS blockers, such as ACE inhibitors and ARBs, as the treatment of choice for patients with renal impairment [108]. Other antihypertensives may be added if BP is not controlled. In addition, the issue of tolerability and adverse events, particularly the occurrence of ACE inhibitor-induced cough, supports the use of ARBs rather than ACE inhibitors in combination therapy in patients with renal impairment [129].

\section{Summary and conclusion}

It is now accepted that most hypertensive patients will not reach and maintain BP goal on monotherapy. Therefore, initial combination therapy is being increasingly used and recommended by guidelines, particularly for patients with $\mathrm{CV}$ risk factors, such as a history of prior $\mathrm{CV}$ events, comorbid diabetes mellitus, microalbuminuria and evidence of organ damage, such as renal disease [7]. Guidelines also recommend the use of SPCs over freedrug combinations due to their improved adherence [7]. In patients with evidence of renal disease or in those with a greater risk of developing renal disease, such as those with diabetes and high-normal BP or overt hypertension, guidelines clearly recommend RAS blocker-based combination therapy due to superior renoprotective effects compared with other classes of antihypertensive agent [7]. Combinations containing an ARB rather than an ACE inhibitor may be preferred because ARBs are associated with superior tolerability, which may lead to improved adherence. In patients with T2DM with proteinuria and/or renal insufficiency, ARB-based treatment is recommended because these agents delay the progression of nephropathy (Table 5).

Two-drug, ARB-based SPCs are available in combination with either HCTZ or amlodipine. Telmisartan, a long-acting ARB with superior 24-hour BP-lowering efficacy compared with several other ARBs, and the only ARB with an indication for the prevention of $\mathrm{CV}$ disease progression, is available in two SPC formulations: telmisartan/ HCTZ and telmisartan/amlodipine. Reaching a decision about which of these to use in a hypertensive patient with evidence of renal impairment is difficult in the absence of clinical trial data. However, evidence from the ACCOMPLISH trial supports the use of a RAS blocker combined with a CCB, rather than HCTZ, for high CV risk hypertensive patients, such as those with coronary artery disease with or without stable angina, patients with a metabolic 
Table 5 Preferred antihypertensive agents based on subclinical organ damage, clinical events and comorbid conditions [6]

\begin{tabular}{|c|c|c|c|c|c|}
\hline & ARBs & ACE inhibitors & CCBs & Diuretics & $\beta$-blockers \\
\hline Uncomplicated hypertension & + & + & + & + & - \\
\hline Renal dysfunction & + & + & - & - & - \\
\hline ESRD/proteinuria & + & + & - & Loop diuretics & - \\
\hline Metabolic syndrome & + & + & + & - & - \\
\hline Diabetes mellitus & + & + & - & - & - \\
\hline Isolated systolic hypertension in the elderly & - & - & + & + & - \\
\hline
\end{tabular}

Abbreviations: $\mathrm{ACE}=$ angiotensin-converting enzyme; $\mathrm{ARBs}=$ angiotensin II receptor blockers; CCBs = calcium channel blockers; ESRD = end-stage renal disease.

risk profile and particularly for those with renal disease $[110,111]$. Data demonstrating beneficial metabolic and inflammatory effects with $\mathrm{ARB} / \mathrm{CCB}$ combined therapy (versus ARB/HCTZ therapy), may also lead to the preferred use of RAS blocker-CCB combinations to achieve further BP reductions whilst avoiding further metabolic disturbances and protecting the kidneys from further damage [116]. However, in hypertensive patients at increased $\mathrm{CV}$ risk requiring an antihypertensive agent that specifically reduces blood volume, the combination of an ARB to protect the kidneys and a thiazide diuretic might be the treatment of choice.

There is a wide range of antihypertensive combinations to choose from and selecting the most appropriate treatment regimen for an individual patient with, or at risk of, renal impairment must depend on a number of considerations: careful review of the patient; the pharmacokinetic/pharmacodynamics properties of the available treatment agents; and the available clinical evidence from outcome studies.

\section{Author information}

Division of Nephrology and Hypertension, Department of Internal Medicine, Faculty of Medicine, American University of Beirut, Riad El-Solh, Beirut 1107 2020, Lebanon.

\footnotetext{
Abbreviations

ACE: Angiotensin-converting enzyme; ACCOMPLISH: Avoiding Cardiovascular events through Combination therapy in Patients Living with Systolic Hypertension; $\mathrm{AMADEO}^{\circledR}{ }_{\circledast}$ : A trial to compare telMisartan $40 \mathrm{mg}$ titrated to $80 \mathrm{mg}$ versus losArtan $50 \mathrm{mg}$ titrated to $100 \mathrm{mg}$ in hypertensive type 2 DiabEtic patients with Overt nephropathy; ARB: Angiotensin II receptor blocker; BP: Blood pressure; CALM: CAndesartan and Lisinopril Microalbuminuria; CCB: Calcium channel blocker; Cl: Confidence interval; CV: Cardiovascular; DBP: Diastolic blood pressure; DETAIL ${ }^{{ }_{\oplus}}$ : Diabetics Exposed to Telmisartan And enalaprIL; DRI: Direct renin inhibitor; ESRD: End-stage renal disease; GFR: Glomerular filtration rate; HCTZ: Hydrochlorothiazide; HOPE: Heart outcomes prevention evaluation; HR: Hazard ratio; IDNT: Irbesartan type II Diabetic Nephropathy Trial; IHSB: International Society on Hypertension in Blacks; IRMA2: IRbesartan in patients with type 2 diabetes and MicroAlbuminuria; MARVAL: MicroAlbuminuria Reduction with VALsartan; ONTARGET ${ }^{\mathbb{B}_{\circledast}}$ : ONgoing Telmisartan Alone and in combination with Ramipril Global Endpoint Trial; RAS: Renin-angiotensin system; RENAAL: Reduction of endpoints in NIDDM with the angiotensin II antagonist losartan; ROADMAP: Randomized olmesartan and diabetes microalbuminuria
}

prevention; SBP: Systolic blood pressure; SMOOTH $H_{\oplus: \text { Study of Micardis }}^{\mathbb{R}_{\circledast}}$ on Obese/Overweight Type-2 diabetics with hypertension; SPC: Single-pill combination; $\mathrm{t}_{1 / 2}$ : Terminal elimination half-life; T2DM: Type 2 diabetes mellitus; $t_{\text {max }}$ : Time to maximum plasma concentration; TRANSCEND ${ }^{\mathbb{B}_{\circledast}}$ : Telmisartan Randomized AssessmeNt Study in ACE-I iNtolerant subjects with cardiovascular disease; UACR: Urine albumin-to-creatinine ratio; Vd: Volume

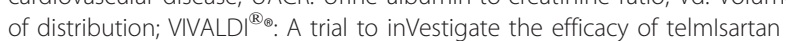
versus VALsartan in hypertensive type 2 Dlabetic patients with overt nephropathy.

Writing and editorial assistance was provided by Emma Fulkes, PhD, of PAREXEL, which was contracted by Boehringer Ingelheim for these services. The author meets criteria for authorship, as recommended by the International Committee of Medical Journal Editors (ICMJE), is fully responsible for all content and editorial decisions, and was involved at all stages of manuscript development. The author received no compensation related to the development of the manuscript.

\section{Authors' contributions}

MS was solely responsible for the conception and content of this review.

\section{Competing interests}

The authors declare that they have no competing interests.

Received: 11 December 2011 Accepted: 10 April 2012

Published: 10 April 2012

\section{References}

1. Egan BM, Zhao $Y$, Axon RN: US trends in prevalence, awareness, treatment, and control of hypertension, 1988-2008. JAMA 2010, 303(20):2043-2050

2. Ezzati M, Oza S, Danaei G, Murray CJ: Trends and cardiovascular mortality effects of state-level blood pressure and uncontrolled hypertension in the United States. Circulation 2008, 117(7):905-914.

3. Ostchega Y, Dillon CF, Hughes JP, Carroll M, Yoon S: Trends in hypertension prevalence, awareness, treatment, and control in older U.S. adults: data from the National Health and Nutrition Examination Survey 1988 to 2004. J Am Geriatr Soc 2007, 55(7):1056-1065.

4. Krause T, Lovibond K, Caulfield M, McCormack T, Williams B: Management of hypertension: summary of NICE guidance. BMJ 2011, 343:d4891.

5. Chobanian AV, Bakris GL, Black HR, Cushman WC, Green LA, Izzo JL Jr, Jones DW, Materson BJ, Oparil S, Wright JT Jr, Roccella EJ: Seventh report of the Joint National Committee on Prevention, Detection, Evaluation, and Treatment of High Blood Pressure. Hypertension 2003, 42(6):1206-1252.

6. Mancia G, De BG, Dominiczak A, Cifkova R, Fagard R, Germano G, Grassi G, Heagerty AM, Kjeldsen SE, Laurent S, Narkiewicz K, Ruilope L, Rynkiewicz A, Schmieder RE, Boudier HA, Zanchetti A, Vahanian A, Camm J, De CR, Dean V, Dickstein K, Filippatos G, Funck-Brentano C, Hellemans I, Kristensen SD, McGregor K, Sechtem U, Silber S, Tendera M, Widimsky P, Zamorano JL, Erdine S, Kiowski W, Agabiti-Rosei E, Ambrosioni E, Lindholm LH, Viigimaa M, Adamopoulos S, Agabiti-Rosei E, Ambrosioni $E_{\text {, }}$ Bertomeu V, Clement D, Erdine S, Farsang C, Gaita D, Lip G, Mallion JM, Manolis AJ, Nilsson PM, O'Brien E, Ponikowski P, Redon J, Ruschitzka F, Tamargo J, Van ZP, Waeber B, Williams B: 2007 Guidelines for the Management of Arterial Hypertension: The Task Force for the 
Management of Arterial Hypertension of the European Society of Hypertension (ESH) and of the European Society of Cardiology (ESC). J Hypertens 2007, 25(6):1105-1187.

7. Mancia G, Laurent S, Agabiti-Rosei E, Ambrosioni E, Burnier M, Caulfield MJ, Cifkova R, Clement D, Coca A, Dominiczak A, Erdine S, Fagard R, Farsang C, Grassi G, Haller H, Heagerty A, Kjeldsen SE, Kiowski W, Mallion JM, Manolis A, Narkiewicz K, Nilsson P, Olsen MH, Rahn KH, Redon J, Rodicio J, Ruilope L, Schmieder RE, Struijker-Boudier HA, van Zwieten PA, Viigimaa M, Zanchetti A: Reappraisal of European guidelines on hypertension management: a European Society of Hypertension Task Force document. J Hypertens 2009, 27(11):2121-2158.

8. Ogihara T, Kikuchi K, Matsuoka H, Fujita T, Higaki J, Horiuchi M, Imai Y Imaizumi T, Ito S, Iwao H, Kario K, Kawano Y, Kim-Mitsuyama S, Kimura G, Matsubara H, Matsuura H, Naruse M, Saito I, Shimada K, Shimamoto K, Suzuki H, Takishita S, Tanahashi N, Tsuchihashi T, Uchiyama M, Ueda S, Ueshima H, Umemura S, Ishimitsu T, Rakugi H: The Japanese Society of Hypertension Guidelines for the Management of Hypertension (JSH 2009). Hypertens Res 2009, 32(1):3-107.

9. Dickson M, Plauschinat CA: Compliance with antihypertensive therapy in the elderly: a comparison of fixed-dose combination amlodipine/ benazepril versus component-based free-combination therapy. Am $J$ Cardiovasc Drugs 2008, 8(1):45-50.

10. Frank J: Managing hypertension using combination therapy. Am Fam Physician 2008, 77(9):1279-1286

11. Bangalore S, Kamalakkannan G, Parkar S, Messerli FH: Fixed-dose combinations improve medication compliance: a meta-analysis. Am J Med 2007, 120(8):713-719.

12. Gupta AK, Arshad S, Poulter NR: Compliance, safety, and effectiveness of fixed-dose combinations of antihypertensive agents: a meta-analysis. Hypertension 2010, 55(2):399-407.

13. Zeng F, Patel BV, Andrews L, Frech-Tamas F, Rudolph AE: Adherence and persistence of single-pill $A R B / C C B$ combination therapy compared to multiple-pill ARB/CCB regimens. Curr Med Res Opin 2010, 26(12):2877-2887.

14. NICE Guidelines: Management of hypertension in adults in primary care. 2011. 2011

15. Lewington S, Clarke R, Qizilbash N, Peto R, Collins R: Age-specific relevance of usual blood pressure to vascular mortality: a meta-analysis of individual data for one million adults in 61 prospective studies. Lancet 2002, 360(9349):1903-1913

16. Law MR, Wald NJ, Morris JK, Jordan RE: Value of low dose combination treatment with blood pressure lowering drugs: analysis of 354 randomised trials. BMJ 2003, 326(7404):1427.

17. Neutel JM: Prescribing patterns in hypertension: the emerging role of fixed-dose combinations for attaining BP goals in hypertensive patients. Curr Med Res Opin 2008, 24(8):2389-2401.

18. Chrysant SG, Murray AV, Hoppe UC, Dattani D, Patel S, Hsu H, Zhang J: Long-term safety, tolerability and efficacy of aliskiren in combination with valsartan in patients with hypertension: a 6-month interim analysis. Curr Med Res Opin 2008, 24(4):1039-1047.

19. Khosla N, Kalaitzidis R, Bakris GL: Predictors of hyperkalemia risk following hypertension control with aldosterone blockade. Am J Nephrol 2009, 30(5):418-424.

20. Wald DS, Law M, Morris JK, Bestwick JP, Wald NJ: Combination therapy versus monotherapy in reducing blood pressure: meta-analysis on 11,000 participants from 42 trials. Am J Med 2009, 122(3):290-300.

21. Pimenta $\mathrm{E}$, Oparil S: Fixed combinations in the management of hypertension: patient perspectives and rationale for development and utility of the olmesartan-amlodipine combination. Vasc Health Risk Manag 2008, 4(3):653-664

22. Bohm M, Thoenes M, Danchin N, Bramlage P, La PP, Volpe M: Association of cardiovascular risk factors with microalbuminuria in hypertensive individuals: the i-SEARCH global study. J Hypertens 2007, 25(11):2317-2324.

23. Gradman AH, Basile JN, Carter BL, Bakris GL: Combination therapy in hypertension. J Clin Hypertens (Greenwich ) 2011, 13(3):146-154

24. Flack JM, Sica DA, Bakris G, Brown AL, Ferdinand KC, Grimm RH Jr, Hall WD, Jones WE, Kountz DS, Lea JP, Nasser S, Nesbitt SD, Saunders E, ScisneyMatlock M, Jamerson KA: Management of high blood pressure in Blacks: an update of the International Society on Hypertension in Blacks consensus statement. Hypertension 2010, 56(5):780-800.
25. Mogensen CE, Neldam S, Tikkanen I, Oren S, Viskoper R, Watts RW, Cooper ME: Randomised controlled trial of dual blockade of reninangiotensin system in patients with hypertension, microalbuminuria, and non-insulin dependent diabetes: the candesartan and lisinopril microalbuminuria (CALM) study. BMJ 2000, 321(7274):1440-1444.

26. Mann JF, Schmieder RE, McQueen M, Dyal L, Schumacher H, Pogue J, Wang X, Maggioni A, Budaj A, Chaithiraphan S, Dickstein K, Keltai M, Metsarinne K, Oto A, Parkhomenko A, Piegas LS, Svendsen TL, Teo KK, Yusuf S: Renal outcomes with telmisartan, ramipril, or both, in people at high vascular risk (the ONTARGET study): a multicentre, randomised, double-blind, controlled trial. Lancet 2008, 372(9638):547-553.

27. Pfeffer MA, McMurray JJ, Velazquez EJ, Rouleau JL, Kober L, Maggioni AP, Solomon SD, Swedberg K, Van de Werf F, White H, Leimberger JD, Henis M, Edwards S, Zelenkofske S, Sellers MA, Califf RM: Valsartan, captopril, or both in myocardial infarction complicated by heart failure, left ventricular dysfunction, or both. N Engl J Med 2003, 349(20):1893-1906.

28. Solomon SD, Appelbaum E, Manning WJ, Verma A, Berglund T, Lukashevich V, Cherif PC, Smith BA, Dahlof B: Effect of the direct Renin inhibitor aliskiren, the Angiotensin receptor blocker losartan, or both on left ventricular mass in patients with hypertension and left ventricular hypertrophy. Circulation 2009, 119(4):530-537.

29. Tobe SW, Clase CM, Gao P, McQueen M, Grosshennig A, Wang X, Teo KK, Yusuf S, Mann JF: Cardiovascular and renal outcomes with telmisartan, ramipril, or both in people at high renal risk: results from the ONTARGET and TRANSCEND studies. Circulation 2011, 123(10):1098-1107.

30. Bangalore S, Kumar S, Messerli FH: Angiotensin-converting enzyme inhibitor associated cough: deceptive information from the Physicians' Desk Reference. Am J Med 2010, 123(11):1016-1030.

31. Weber MA, Messerli FH: Angiotensin-converting enzyme inhibitors and angioedema: estimating the risk. Hypertension 2008, 51(6):1465-1467.

32. Yusuf S, Teo KK, Pogue J, Dyal L, Copland I, Schumacher H, Dagenais G, Sleight P, Anderson C: Telmisartan, ramipril, or both in patients at high risk for vascular events. N Engl I Med 2008, 358(15):1547-1559.

33. Lacourciere Y: A multicenter, randomized, double-blind study of the antihypertensive efficacy and tolerability of irbesartan in patients aged $>$ or $=65$ years with mild to moderate hypertension. Clin Ther 2000, 22(10):1213-1224.

34. Yusuf S, Teo K, Anderson C, Pogue J, Dyal L, Copland I, Schumacher H, Dagenais G, Sleight P: Effects of the angiotensin-receptor blocker telmisartan on cardiovascular events in high-risk patients intolerant to angiotensin-converting enzyme inhibitors: a randomised controlled trial. Lancet 2008, 372(9644):1174-1183.

35. Corrao G, Zambon A, Parodi A, Poluzzi E, Baldi I, Merlino L, Cesana G, Mancia G: Discontinuation of and changes in drug therapy for hypertension among newly-treated patients: a population-based study in Italy. J Hypertens 2008, 26(4):819-824.

36. Kjeldsen SE, Os I, Hoieggen A, Beckey K, Gleim GW, Oparil S: Fixed-dose combinations in the management of hypertension: defining the place of angiotensin receptor antagonists and hydrochlorothiazide. Am J Cardiovasc Drugs 2005, 5(1):17-22

37. Littlejohn TW III, Majul CR, Olvera R, Seeber M, Kobe M, Guthrie R, Oigman W: Telmisartan plus amlodipine in patients with moderate or severe hypertension: results from a subgroup analysis of a randomized, placebo-controlled, parallel-group, $4 \times 4$ factorial study. Postgrad Med 2009, 121(2):5-14.

38. Makani H, Bangalore S, Romero J, Wever-Pinzon O, Messerli FH: Effect of renin-angiotensin system blockade on calcium channel blockerassociated peripheral edema. Am J Med 2011, 124(2):128-135.

39. Oparil S, Weber M: Angiotensin receptor blocker and dihydropyridine calcium channel blocker combinations: an emerging strategy in hypertension therapy. Postgrad Med 2009, 121(2):25-39.

40. Philipp T, Smith TR, Glazer R, Wernsing M, Yen J, Jin J, Schneider H, Pospiech R: Two multicenter, 8-week, randomized, double-blind, placebo-controlled, parallel-group studies evaluating the efficacy and tolerability of amlodipine and valsartan in combination and as monotherapy in adult patients with mild to moderate essential hypertension. Clin Ther 2007, 29(4):563-580.

41. Fletcher A, Bulpitt C: Quality of life in the treatment of hypertension. The effect of calcium antagonists. Drugs 1992, 44(Suppl 1):135-140. 
42. Pedrinelli R, Dell'Omo G, Mariani M: Calcium channel blockers, postural vasoconstriction and dependent oedema in essential hypertension. $J$ Hum Hypertens 2001, 15(7):455-461.

43. de la Sierra A: Mitigation of calcium channel blocker-related oedema in hypertension by antagonists of the renin-angiotensin system. J Hum Hypertens 2009, 23(8):503-511.

44. Makani H, Bangalore S, Romero J, Wever-Pinzon O, Messerli FH: Effect of renin-angiotensin system blockade on calcium channel blockerassociated peripheral edema. Am J Med 2011, 124(2):128-135.

45. Fogari R, Mugellini A, Zoppi A, Lazzari P, Destro M, Rinaldi A, Preti P: Effect of telmisartan/hydrochlorothiazide vs lisinopril/hydrochlorothiazide combination on ambulatory blood pressure and cognitive function in elderly hypertensive patients. J Hum Hypertens 2006, 20(3):177-185.

46. Gosse P, Neutel JM, Schumacher H, Lacourciere Y, Williams B, Davidai G: The effect of telmisartan and ramipril on early morning blood pressure surge: a pooled analysis of two randomized clinical trials. Blood Press Monit 2007, 12(3):141-147.

47. Lacourciere Y, Neutel JM, Davidai G, Koval S: A multicenter, 14-week study of telmisartan and ramipril in patients with mild-to-moderate hypertension using ambulatory blood pressure monitoring. Am J Hypertens 2006, 19(1):104-112.

48. Nalbantgil I, Nalbantgil S, Ozerkan F, Yilmaz H, Gurgun C, Zoghi M, Aytimur M, Onder R: The efficacy of telmisartan compared with perindopril in patients with mild-to-moderate hypertension. Int J Clin Pract Suppl 2004, 145:50-54.

49. Ragot S, Ezzaher A, Meunier A, Poterre M, Bourkaib R, Herpin D: Comparison of trough effect of telmisartan vs perindopril using self blood pressure measurement: EVERESTE study. J Hum Hypertens 2002, 16(12):865-873.

50. Williams B, Gosse P, Lowe L, Harper R: The prospective, randomized investigation of the safety and efficacy of telmisartan versus ramipril using ambulatory blood pressure monitoring (PRISMA I). J Hypertens 2006, 24(1):193-200.

51. Nishida Y, Takahashi $Y$, Nakayama T, Soma M, Asai S: Comparative effect of olmesartan and candesartan on lipid metabolism and renal function in patients with hypertension: a retrospective observational study. Cardiovasc Diabetol 2011, 10:74.

52. Nishida Y, Takahashi Y, Nakayama T, Soma M, Kitamura N, Asai S: Effect of candesartan monotherapy on lipid metabolism in patients with hypertension: a retrospective longitudinal survey using data from electronic medical records. Cardiovasc Diabetol 2010, 9:38.

53. Sipahi I, Debanne SM, Rowland DY, Simon DI, Fang JC: Angiotensinreceptor blockade and risk of cancer: meta-analysis of randomised controlled trials. Lancet Oncol 2010, 11(7):627-636.

54. Effects of telmisartan, irbesartan, valsartan, candesartan, and losartan on cancers in 15 trials enrolling 138,769 individuals. J Hypertens 2011, 29(4):623-635.

55. Bangalore S, Kumar S, Kjeldsen SE, Makani H, Grossman E, Wetterslev J, Gupta AK, Sever PS, Gluud C, Messerli FH: Antihypertensive drugs and risk of cancer: network meta-analyses and trial sequential analyses of 324,168 participants from randomised trials. Lancet Oncol 2011, 12(1):65-82

56. Izzo $J \mathrm{~L} J \mathrm{r}$, Zion AS: Value of Angiotensin receptor blocker therapy in diabetes. J Clin Hypertens (Greenwich ) 2011, 13(4):290-295.

57. American Diabetes Association: Standards of medical care in diabetes. Diabetes Care 2008, 31(Suppl 1):12-54

58. Trimarchi H: Role of aliskiren in blood pressure control and renoprotection. Int J Nephrol Renovasc Dis 2011, 4:41-48.

59. Parving HH, Brenner BM, McMurray JJ, de ZD, Haffner SM, Solomon SD, Chaturvedi N, Ghadanfar M, Weissbach N, Xiang Z, Armbrecht J, Pfeffer MA: Aliskiren Trial in Type 2 Diabetes Using Cardio-Renal Endpoints (ALTITUDE): rationale and study design. Nephrol Dial Transplant 2009, 24(5):1663-1671

60. Chrysant SG, Chrysant GS: Antihypertensive efficacy of olmesartan medoxomil alone and in combination with hydrochlorothiazide. Expert Opin Pharmacother 2004, 5(3):657-667.

61. Flack JM: Maximising antihypertensive effects of angiotensin II receptor blockers with thiazide diuretic combination therapy: focus on irbesartan/hydrochlorothiazide. Int J Clin Pract 2007, 61(12):2093-2102.

62. Lacourciere $Y$, Poirier L, Hebert D, Assouline L, Stolt P, Rehel B, Khder Y: Antihypertensive efficacy and tolerability of two fixed-dose combinations of valsartan and hydrochlorothiazide compared with valsartan monotherapy in patients with stage 2 or 3 systolic hypertension: an 8-week, randomized, double-blind, parallel-group trial. Clin Ther 2005, 27(7):1013-1021.

63. Ram CV: Antihypertensive efficacy of angiotensin receptor blockers in combination with hydrochlorothiazide: a review of the factorial-design studies. J Clin Hypertens (Greenwich ) 2004, 6(10):569-577.

64. Brachmann J, Ansari A, Mahla G, Handrock R, Klebs S: Effective and safe reduction of blood pressure with the combination of amlodipine $5 \mathrm{mg}$ and valsartan $160 \mathrm{mg}$ in hypertensive patients not controlled by calcium channel blocker monotherapy. Adv Ther 2008, 25(5):399-411.

65. Chrysant SG, Melino M, Karki S, Lee J, Heyrman R: The combination of olmesartan medoxomil and amlodipine besylate in controlling high blood pressure: $\mathrm{COACH}$, a randomized, double-blind, placebo-controlled, 8-week factorial efficacy and safety study. Clin Ther 2010, 24:587-604.

66. Chrysant SG, Lee J, Melino M, Karki S, Heyrman R: Efficacy and tolerability of amlodipine plus olmesartan medoxomil in patients with difficult-totreat hypertension. J Hum Hypertens 2010, 24(11):730-738.

67. Hasebe N, Kikuchi K: Controlled-release nifedipine and candesartan lowdose combination therapy in patients with essential hypertension: the NICE Combi (Nifedipine and Candesartan Combination) Study. J Hypertens 2005, 23(2):445-453.

68. Smith TR, Philipp T, Vaisse B, Bakris GL, Wernsing M, Yen J, Glazer R: Amlodipine and valsartan combined and as monotherapy in stage 2 , elderly, and black hypertensive patients: subgroup analyses of 2 randomized, placebo-controlled studies. J Clin Hypertens (Greenwich) 2007, 9(5):355-364.

69. European Medicines Agency: List of authorised medicines for hypertension. 2011, Available from: European Medicines Agency. 2011.

70. Burnier M: Telmisartan: a different angiotensin II receptor blocker protecting a different population? J Int Med Res 2009, 37(6):1662-1679.

71. Song JC, White CM: Olmesartan medoxomil (CS-866). An angiotensin II receptor blocker for treatment of hypertension. Formulary 2001, 35:487-499.

72. Kakuta H, Sudoh K, Sasamata M, Yamagishi S: Telmisartan has the strongest binding affinity to angiotensin II type 1 receptor: comparison with other angiotensin II type 1 receptor blockers. Int J Clin Pharmacol Res 2005, 25(1):41-46.

73. Wienen W, Entzeroth M, an Meel JCA: A review on telmisartan: a novel, long-acting angiotensin II-receptor antagonist. CardiovasC Drug Rev 2000, 18:127-154.

74. Jugdutt Bl: Clinical effectiveness of telmisartan alone or in combination therapy for controlling blood pressure and vascular risk in the elderly. Clin Interv Aging 2010, 5:403-416.

75. Tuck ML: Angiotensin-receptor blocking agents and the peroxisome proliferator-activated receptor-gamma system. Curr Hypertens Rep 2005, 7(4):240-243.

76. Galzerano D, Capogrosso C, Di MS, Galzerano A, Paparello P, Lama D, Gaudio C: New standards in hypertension and cardiovascular risk management: focus on telmisartan. Vasc Health Risk Manag 2010, 6:113-133.

77. Unger $T$, Paulis $L$, Sica DA: Therapeutic perspectives in hypertension: novel means for renin-angiotensin-aldosterone system modulation and emerging device-based approaches. Eur Heart J 2011, 32(22):2739-2747.

78. Cao Z, Cooper ME: Efficacy of renin-angiotensin system (RAS) blockers on cardiovascular and renal outcomes in patients with type 2 diabetes. Acta Diabetol 2011

79. Azilsartan Medoxomil Prescribing Information. 2012.

80. Ding PY, Chu KM, Chiang HT, Shu KH: A double-blind ambulatory blood pressure monitoring study of the efficacy and tolerability of once-daily telmisartan $40 \mathrm{mg}$ in comparison with losartan $50 \mathrm{mg}$ in the treatment of mild-to-moderate hypertension in Taiwanese patients. Int J Clin Pract Suppl 2004, 145:16-22.

81. Lacourciere Y, Krzesinski JM, White WB, Davidai G, Schumacher H: Sustained antihypertensive activity of telmisartan compared with valsartan. Blood Press Monit 2004, 9(4):203-210.

82. Mallion JM, Baguet JP, Siche JP, Tremel F, De GR: Cardiac and vascular remodelling: effect of antihypertensive agents. J Hum Hypertens 1999, 13(Suppl 1):S35-S41.

83. Nishimura T, Hashimoto J, Ohkubo T, Kikuya M, Metoki H, Asayama K, Totsune K, Imai Y: Efficacy and duration of action of the four selective 
angiotensin II subtype 1 receptor blockers, losartan, candesartan, valsartan and telmisartan, in patients with essential hypertension determined by home blood pressure measurements. Clin Exp Hypertens 2005, 27(6):477-489.

84. Sasaki T, Noda Y, Yasuoka Y, Irino H, Abe H, Adachi H, Hattori S, Kitada H, Morisawa D, Miyatake K: Comparison of the effects of telmisartan and olmesartan on home blood pressure, glucose, and lipid profiles in patients with hypertension, chronic heart failure, and metabolic syndrome. Hypertens Res 2008, 31(5):921-929.

85. Smith DH, Cramer MJ, Neutel JM, Hettiarachchi R, Koval S: Comparison of telmisartan versus losartan: meta-analysis of titration-to-response studies. Blood Press Monit 2003, 8(3):111-117.

86. White WB, Lacourciere Y, Davidai G: Effects of the angiotensin II receptor blockers telmisartan versus valsartan on the circadian variation of blood pressure: impact on the early morning period. Am J Hypertens 2004, 17(4):347-353.

87. Parati G, Schumacher H, Bilo G, Mancia G: Evaluating 24-h antihypertensive efficacy by the smoothness index: a meta-analysis of an ambulatory blood pressure monitoring database. J Hypertens 2010, 28(11):2177-2183.

88. Littlejohn T, Mroczek W, Marbury T, VanderMaelen CP, Dubiel RF: A prospective, randomized, open-label trial comparing telmisartan $80 \mathrm{mg}$ with valsartan $80 \mathrm{mg}$ in patients with mild to moderate hypertension using ambulatory blood pressure monitoring. Can J Cardiol 2000, 16(9):1123-1132

89. Sharma AM, Hollander A, Koster J: Telmisartan in patients with mild/ moderate hypertension and chronic kidney disease. Clin Nephrol 2005 63(4):250-257

90. Lacourciere Y, Tytus R, O'Keefe D, Lenis J, Orchard R, Martin K: Efficacy and tolerability of a fixed-dose combination of telmisartan plus hydrochlorothiazide in patients uncontrolled with telmisartan monotherapy. J Hum Hypertens 2001, 15(11):763-770.

91. McGill JB, Reilly PA: Telmisartan plus hydrochlorothiazide versus telmisartan or hydrochlorothiazide monotherapy in patients with mild to moderate hypertension: a multicenter, randomized, double-blind, placebo-controlled, parallel-group trial. Clin Ther 2001, 23(6):833-850.

92. Neutel JM, Littlejohn TW, Chrysant SG, Singh A: Telmisartan/ Hydrochlorothiazide in comparison with losartan/hydrochlorothiazide in managing patients with mild-to-moderate hypertension. Hypertens Res 2005, 28(7):555-563.

93. Sharma AM, Davidson J, Koval S, Lacourciere Y: Telmisartan/ hydrochlorothiazide versus valsartan/hydrochlorothiazide in obese hypertensive patients with type 2 diabetes: the SMOOTH study. Cardiovasc Diabetol 2007, 6:28.

94. White WB, Davidai $G$, Schumacher $H$ : Impact of angiotensin receptor blockade in combination with hydrochlorothiazide $25 \mathrm{mg}$ in 2121 patients with stage 1-2 hypertension. J Hum Hypertens 2009, 23(12):817-825.

95. Littlejohn TW III, Majul CR, Olvera R, Seeber M, Kobe M, Guthrie R, Oigman W: Results of treatment with telmisartan-amlodipine in hypertensive patients. J Clin Hypertens (Greenwich) 2009, 11(4):207-213.

96. Sharma A, Bagchi A, Kinagi SB, Sharma YK, Baliga VP, Bollmall C: Results of a comparative, phase III, 12-week, multicenter, prospective, randomized, double-blind assessment of the efficacy and tolerability of a fixed-dose combination of telmisartan and amlodipine versus amlodipine monotherapy in Indian adults with stage II hypertension. Clin Ther 2007, 29(12):2667-2676.

97. Lacourciere Y, Gil-Extremera B, Mueller O, Byrne M, Williams L: Efficacy and tolerability of fixed-dose combinations of telmisartan plus $\mathrm{HCTZ}$ compared with losartan plus HCTZ in patients with essential hypertension. Int J Clin Pract 2003, 57(4):273-279.

98. Lacourciere Y, Neutel JM, Schumacher H: Comparison of fixed-dose combinations of telmisartan/hydrochlorothiazide $40 / 12.5 \mathrm{mg}$ and $80 /$ $12.5 \mathrm{mg}$ and a fixed-dose combination of losartan/hydrochlorothiazide $50 / 12.5 \mathrm{mg}$ in mild to moderate essential hypertension: pooled analysis of two multicenter, prospective, randomized, open-label, blinded-end point (PROBE) trials. Clin Ther 2005, 27(11):1795-1805.

99. Barnett AH, Bain SC, Bouter P, Karlberg B, Madsbad S, Jervell J, Mustonen J: Angiotensin-receptor blockade versus converting-enzyme inhibition in type 2 diabetes and nephropathy. N Engl J Med 2004, 351(19):1952-1961.
100. Abe M, Okada K, Maruyama T, Matsumoto S, Matsumoto K: Blood pressurelowering and antiproteinuric effect of switching from high-dose angiotensin receptor blockers to normal-dose telmisartan and low-dose hydrochlorothiazide in hypertensive patients with chronic kidney disease. Int J Clin Pharmacol Ther 2010, 48(3):206-213.

101. Schumacher $H$, Mancia G: The safety profile of telmisartan as monotherapy or combined with hydrochlorothiazide: a retrospective analysis of 50 studies. Blood Press Suppl 2008, 1:32-40.

102. Abe M, Okada K, Matsumoto K: Clinical experience in treating hypertension with fixed-dose combination therapy: angiotensin II receptor blocker losartan plus hydrochlorothiazide. Expet Opin Drug Metabol Toxicol 2009, 5(10):1285-1303.

103. Black HR, Bailey J, Zappe D, Samuel R: Valsartan: more than a decade of experience. Drugs 2009, 69(17):2393-2414

104. Neutel JM, Franklin SS, Bhaumik A, Lapuerta P, Oparil S: Safety and tolerability of fixed-dose irbesartan/hydrochlorothiazide for rapid control of severe hypertension. Clin Exp Hypertens 2009, 31(7):572-584.

105. White WB, Littlejohn TW, Majul CR, Oigman W, Olvera R, Seeber M, Schumacher $H$, Mancia G: Effects of telmisartan and amlodipine in combination on ambulatory blood pressure in stages 1-2 hypertension. Blood Press Monit 2010, 15(4):205-212.

106. Guthrie RM, Dahlof B, Jamerson KA, Olvera R, Seeber M, Schumacher $H$, Oigman W: Efficacy and tolerability of telmisartan plus amlodipine in added-risk hypertensive patients. Curr Med Res Opin 2011, 27(10):1995-2008.

107. Sharma AM, Bakris G, Neutel JM, Littlejohn TW, Kobe M, Ting N, Ley L: Single-Pill Combination of Telmisartan/Amlodipine vs Amlodipine Monotherapy in Diabetic Hypertensive Patients: an 8-week randomised, parallel group, double blind trial. Clin Ther 2011.

108. Kidney Disease Outcomes Quality Initiative (K/DOQI): K/DOQI clinical practice guidelines on hypertension and antihypertensive agents in chronic kidney disease. Am J Kidney Dis 2004, 43(5 Suppl 1):S1-S290.

109. Matsui Y, Eguchi K, Ishikawa J, Shimada K, Kario K: Urinary albumin excretion during angiotensin II receptor blockade: comparison of combination treatment with a diuretic or a calcium-channel blocker. Am $J$ Hypertens 2011, 24(4):466-473.

110. Bakris GL, Sarafidis PA, Weir MR, Dahlof B, Pitt B, Jamerson K, Velazquez EJ, Staikos-Byrne L, Kelly RY, Shi V, Chiang YT, Weber MA: Renal outcomes with different fixed-dose combination therapies in patients with hypertension at high risk for cardiovascular events (ACCOMPLISH): a prespecified secondary analysis of a randomised controlled trial. Lancet 2010, 375(9721):1173-1181.

111. Jamerson K, Weber MA, Bakris GL, Dahlof B, Pitt B, Shi V, Hester A, Gupte J, Gatlin M, Velazquez EJ: Benazepril plus amlodipine or hydrochlorothiazide for hypertension in high-risk patients. N Engl J Med 2008, 359(23):2417-2428

112. Jamerson KA, Bakris GL, Weber MA: 24-hour ambulatory blood pressure in the ACCOMPLISH trial. N Engl J Med 2010, 363(1):98.

113. Jamerson KA, Devereux R, Bakris GL, Dahlof B, Pitt B, Velazquez EJ, Weir M, Kelly RY, Hua TA, Hester A, Weber MA: Efficacy and duration of benazepril plus amlodipine or hydrochlorothiazide on 24-hour ambulatory systolic blood pressure control. Hypertension 2011, 57(2):174-179.

114. Cooper-DeHoff RM, Pacanowski MA, Pepine CJ: Cardiovascular therapies and associated glucose homeostasis: implications across the dysglycemia continuum. J Am Coll Cardiol 2009, 53(5 Suppl):S28-S34.

115. Elliott WJ, Meyer PM: Incident diabetes in clinical trials of antihypertensive drugs: a network meta-analysis. Lancet 2007 369(9557):201-207

116. Martinez-Martin FJ, Rodriguez-Rosas H, Peiro-Martinez I, Soriano-Perera P, Pedrianes-Martin P, Comi-Diaz C: Olmesartan/amlodipine vs olmesartan/ hydrochlorothiazide in hypertensive patients with metabolic syndrome: the OLAS study. J Hum Hypertens 2011, 25(6):346-353.

117. Touyz RM: Intracellular mechanisms involved in vascular remodelling of resistance arteries in hypertension: role of angiotensin II. Exp Physiol 2005, 90(4):449-455.

118. Parving HH, Lehnert H, Brochner-Mortensen J, Gomis R, Andersen S, Arner $P$ : The effect of irbesartan on the development of diabetic nephropathy in patients with type 2 diabetes. N Engl J Med 2001, 345(12):870-878.

119. Lewis EJ, Hunsicker LG, Clarke WR, Berl T, Pohl MA, Lewis JB, Ritz E, Atkins RC, Rohde R, Raz I: Renoprotective effect of the angiotensin- 
receptor antagonist irbesartan in patients with nephropathy due to type 2 diabetes. N Engl J Med 2001, 345(12):851-860

120. Brenner BM, Cooper ME, de ZD, Keane WF, Mitch WE, Parving HH, Remuzzi G, Snapinn SM, Zhang Z, Shahinfar S: Effects of losartan on renal and cardiovascular outcomes in patients with type 2 diabetes and nephropathy. N Engl J Med 2001, 345(12):861-869.

121. Viberti G, Wheeldon NM: Microalbuminuria reduction with valsartan in patients with type 2 diabetes mellitus: a blood pressure-independent effect. Circulation 2002, 106(6):672-678.

122. Bakris $G$, Burgess $E$, Weir M, Davidai $G$, Koval $\mathrm{S}$ : Telmisartan is more effective than losartan in reducing proteinuria in patients with diabetic nephropathy. Kidney Int 2008, 74(3):364-369.

123. Haller H, Ito S, Izzo JL Jr, Januszewicz A, Katayama S, Menne J, Mimran A, Rabelink TJ, Ritz E, Ruilope LM, Rump LC, Viberti G: Olmesartan for the delay or prevention of microalbuminuria in type 2 diabetes. $N$ Engl $J$ Med 2011, 364(10):907-917.

124. Galle J, Schwedhelm E, Pinnetti S, Boger RH, Wanner C: Antiproteinuric effects of angiotensin receptor blockers: telmisartan versus valsartan in hypertensive patients with type 2 diabetes mellitus and overt nephropathy. Nephrol Dial Transplant 2008, 23(10):3174-3183.

125. Yusuf S, Sleight P, Pogue J, Bosch J, Davies R, Dagenais G: Effects of an angiotensin-converting-enzyme inhibitor, ramipril, on cardiovascular events in high-risk patients. The Heart Outcomes Prevention Evaluation Study Investigators. N Engl J Med 2000, 342(3):145-153.

126. Mann JF, Schmieder RE, Dyal L, CQueen M, Schumacher H, Pogue J, Wang X, robstfield JL, Avezum A, Cardona-Munoz E, Dagenais GR, Diaz R, Fodor G, Maillon JM, Rydén L, Yu CM, Teo KK, Yusuf S, TRANSCEND (Telmisartan Randomised Assessment Study in ACE Intolerant Subjects with Cardiovascular Disease) Investigators: Effect of telmisartan on renal outcomes: a randomized trial. Ann Intern Med 2009, 151(1):1-10.

127. Mann JF, Schmieder RE, McQueen M, Dyal L, Schumacher H, Pogue J, Wang X, Maggioni A, Budaj A, Chaithiraphan S, Dickstein K, Keltai M, Metsarinne K, Oto A, Parkhomenko A, Piegas LS, Svendsen TL, Teo KK, Yusuf S: Renal outcomes with telmisartan, ramipril, or both, in people at high vascular risk (the ONTARGET study): a multicentre, randomised, double-blind, controlled trial. Lancet 2008, 372(9638):547-553.

128. Ritz E, Schmieder RE, Pollock CA: Renal protection in diabetes: lessons from ONTARGET. Cardiovasc Diabetol 2010, 9:60

129. Malacco E, Santonastaso M, Vari NA, Gargiulo A, Spagnuolo V, Bertocchi F, Palatini P: Comparison of valsartan $160 \mathrm{mg}$ with lisinopril $20 \mathrm{mg}$, given as monotherapy or in combination with a diuretic, for the treatment of hypertension: the Blood Pressure Reduction and Tolerability of Valsartan in Comparison with Lisinopril (PREVAIL) study. Clin Ther 2004, 26(6):855-865

doi:10.1186/1475-2840-11-32

Cite this article as: Mallat: What is a preferred angiotensin II receptor blocker-based combination therapy for blood pressure control in hypertensive patients with diabetic and non-diabetic renal impairment? Cardiovascular Diabetology 2012 11:32.

\section{Submit your next manuscript to BioMed Central and take full advantage of:}

- Convenient online submission

- Thorough peer review

- No space constraints or color figure charges

- Immediate publication on acceptance

- Inclusion in PubMed, CAS, Scopus and Google Scholar

- Research which is freely available for redistribution

Submit your manuscript at www.biomedcentral.com/submit
Biomed Central 